㐘肉における口腔内の種々の抗原によりヒスタミン遊離または脱顆粒の現象が起り，アレルギー性病変の惹起 が容易に考えられると云い，また形質細胞ならびにリンパ球と帯同的に存在し，形質細胞より産生される IgE ならびに形質細胞およびリンパ球より産生される免疫グロブリンによる防衛的機構が成立し，口腔免疫機序の一 端を解明出来たと結論している.

以上，免疫成立に関する種々の組織および細胞の中でとくに組織肥㭌細胞をとりあげ，免疫に関与する他の形質細 胞およびりンパ球などとの関連性を求めるため口腔領域では比較的広範囲にわたり分布している雪肉を研究対象とし て詳細に観察し, 種々なる新知見を得ており学位論文として価值ある業績と判定した。

氏 名 (本籍) 古 野秋生 (福岡)

学位の種 類雨学博士

学位記 番号 乙 第102号

学位授与日付 昭和 52 年 3 月 31 日

学位授与の要件 博士の学位論文提出者（学位規則第 5 条第 2 項該当者）

学位論文題目功ル舌咽神経の再生に関する実験的研究

論文審査委員 (主査) 教授山田長 敬

(副查) 教授 上 野 正 康

" $"$ 中原敏

\title{
主論文の要旨
}

頻・口腔領域における外傷，手術侵襲などにより，その部位の神経を損傷，切断することがある。このような症例 では知覚，味覚，運動などの障害を訴えてくる，この神経の障害はどのような経過を取り，機能の回復および治療が 進むかをカエル舌咽神経を用い生理学的，病理組織学的実験により検索した。その結果を要約すると次のようであ る。

\section{A. 生理学的実験結果}

1. 舌咽神経剪断後12日まで舌に触刺激，化学刺激を与えても舌咽神経の求心性放電は発生しなかった。

2. 術後13日には 4 例中 1 例ではあるが各刺激に対し, 切断側舌咽神経の求心放電がみられた。他の3 例に応答が なかった。

3. 術後14日より20日までに行なった42例中33例は触刺激，化学刺激のいずれにも応答したが，うち 5 例は触刺激 のみに応答した。

4. 求心性放電の発現初期におういては求心性放電の頻度，振幅はともに小さいが，時日の経過とともに頻度，振幅 が増大した。

B. 病理組織学的検索結果

1. 切断側より末梢の神経線維の変性は, 術後24時間より始まっている.

2. 術後 3〜 6 日頃までに変性は進み, 念珠状変性, 断裂, 顆粓状崩壊などの変性所見が各層にわたりみられ, 茸 状乳頭部においては神経線維の消失がみられる。

3. 術後 7 10日で waller 変性が完了しているようである.

4. 術後10日頃筋層において肥大, 增殖した Schwann 氏細胞が索状に配列し，乙れに沿うように微細な1〜2 本の再生神経と思われるものが見られた。

5. 術後15日頃より茸状乳頭部にも微細な 1〜2本の再生神経がみられ，てれが感覚細胞に向って進んでいる. 時 日の経過とともに再生神経線維は数を増し，径も大きくなっている.

6. 咠状乳頭遊離縁にある感覚細胞は神経の変性, 再生期においても何等変化はなく規則正しく配列している.

C. 生理学的実験結果と病理組織学的検索結果の関連 
1. 淀理組織学的には再生神経を見たのは術後10日に筋層部の一部にみられたが，生理学的に舌刺激による㗳が みられたのは街後13日以後であった。

2. 茸状乳頭部に再生神経を兒たのは術後15日以後であったが，求心性放電は術後13日より見られた。時日の経過 とともに神経の再生は進み，同時に求心性放電の頻度，振幅共に増大した。

3. 病理組織学的に術後35日にいたるも, その分布量において正常神経線維には及ばなかった。また, 求心性放電 の頻度，振幅も正常側に比し少なかった。

\section{論文審查の結果の要旨}

著者はトノサマガエルの舌咽神経を切断し, 術後24時間から35日の間, 舌神経標本を作成し, 舌江触刺激, 化学的 刺激を加光, 求心性放電の発現時期抢よび放電の発生状態を検索し, さらに生理学的実験後の舌を神経染色し, 病理 組織学的㰸索した結果

1. 舌咽神経切断後12日まで舌汇触刺激や化学的刺激を与えても舌咽神経の求心性放電は発生しなかった。

2. 術後13日には 4 例中 1 例ではあるが各刺激に対し, 切断側舌咽神経の求心性放電がみられ, 他の 3 例では応答 が見られなかった。

3. 求心性放電の発現初期に おいては頻度, 挔幅ともに小さいが，日時の経過とともに頻度，振幅ともに增大し た。

4. 切断側より末梢の神経線維の変性は術後24時間で始まっている.

5. 術後 7 日〜10日で Waller 変性が完了しているようである.

6. 術後10日ごろになると筋層において，肥大，堛殖した Schwann 氏細胞が索状酒列し，乙れに沿うように 微細な $1 〜 2$ 本の再生神経と思われるものが見られた。

7. 術後15日貪より茸状乳頭部にも微紐な 1 2 本の再生神経が出現し，乙れらが感覚細胞に向って進んでいる.

8. 茸状乳頭遊離縁にある感覚細胞は神経の変性再生期においても何等変化はなく規則正しく配列している.

9. 苪理組織学的に再生神経を見たのは術後10日に筋層部の一部にみられたが，生理学的に舌刺激による応答がみ られたのは術後13日以後であった。

10. 茸状乳頭部に再生神経を見たのは術後15日以降であったが，求心性放電は術後13日より見られた。

11. 病理組織学的に術後35日にいたるもその分布量において正常神経線維には及ばなかった。生理学的においても 同様に求心性放電の頻度，振幅ともに正常側に比し少かった。

以上の結果，本論文は神経切断後の快復過程を生理学的，病理組織学的立場より観察したもので極めて価值ある論 文と認める。

氏名 (本籍) 加藤 喜 陸(福岡)

学位の種 類 歯学博士

学位記番号 乙 第103号

学位授与日付炤和52年 3 月 31 日

学位授与の要件＼cjkstart博士の学位論文提出者（学位規則第 5 条第 2 項該当者）

学位論文題目 長崎県壱岐勝本住民における頭顔部の生体計測ならびに歯列引との相関について，

論文審查委貪 (主査) 教授 中山種秋

(副查) 教授 荷 宮 文夫

" "山田博

\section{主論文の要旨}

著者は炤和45年（1970）壱岐勝本住民の生体計測を行い，その成績を検討して時代差，特に短頭化の実態を明らか にするとともに，歯列引の諸径との間に，どのような相関関係があるかを知るべく，本研究を企図し次のような結論 を得た。すなおち 